
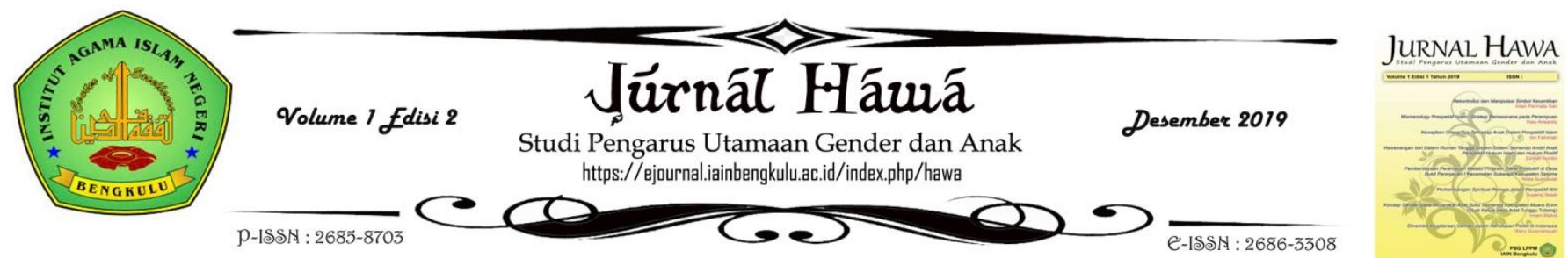

\title{
Motivasi Orang Tua Dalam Memberikan Pendidikan Lanjutan Bagi đnak Di Desa Gunung Besar Keeamatan Arma Jaya Kabupaten Bengkulu Zlara
}

\author{
Resy Mahalelita, Suryani, dan A. Suradi \\ ResyMahalelita1708@gmail.com, Suryanicanut.1@gmail.com, dan suradi@iainbengkulu.ic.id
}

IAIN Bengkulu

\section{Info Artikel}

\section{Diterima:}

Oktober 2019

Disetujui:

Oktober 2019

Dipublikasikan:

Desember 2019

\section{Keyword}

Motivation, Parents,

Children's

Continuing

Education.

\section{Kata Kunci}

Motivasi, orang tua, dan pendidikan lanjutan
Motivation of Parents in Provide Advanced Education for Children In The Village of Gunung Besar, Kecamatan Arma Jaya, Bengkulu Utara District. Parent's motivation in providing further education for children is very important for children in the future. The purpose of this study is for parents to know how motivation is needed by children and to know the factors that influence parents in providing further education for children in Gunung Besar Village, Arma jaya District, North Bengkulu Regency. This study uses a type of field research with a qualitative descriptive approach, research data collected using the method of observation, interviews and documentation. Data collected from these techniques were analyzed using data reduction, data presentation, and data verification, the validity of the data obtained by using data triangulation. The results of this study indicate that: Motivation of parents who have not been maximal in providing encouragement to their children and the environment of children who are less supportive so that children are wrong in getting along, and when viewed from the understanding of parents in interpreting the importance of further education for children parents have started understand how important education is in the future. Factors that influence parents in providing further education for children in the village of Gunung Besar are the child's interest in continuing education, while the external factors are the family environment, economic costs and children's relationships.

\section{Tbstrak}

Motivasi Orang Tua Dalam Memberikan Pendidikan Lanjutan Bagi Anak Di Desa Gunung Besar Kecamatan Arma Jaya Kabupaten Bengkulu Utara. Motivasi orang tua dalam memberikan pendidikan lanjutan bagi anak sangat penting bagi anak dimasa yang akan datang. Tujuan penelitian ini adalah agar orang tua mengetahui motivasi yang diperlukan oleh anak serta untuk mengetahui faktor-faktor yang memperngaruhi orang tua dalam memberikan pendidikan lanjutan bagi anak di Desa Gunung Besar Kecamatan Arma jaya Kabupaten Bengkulu Utara. Penelitian ini menggunakan jenis penelitian lapangan dengan pendekatan deskriptif kualitatif. Data-data penelitian dikumpulkan dengan menggunakan metode observasi, wawancara, dan dokumentasi. Data yang terkumpul dari teknik tersebut dianalisis dengan menggunakan reduksi data, penyajian data, dan verivikasi data, keabsahan data diperoleh dengan menggunakan triangulasi data. Hasil dari penelitian ini menunjukkan bahwa: Motivasi orang tua yang belum maksimal dalam memberikan dorongan kepada anak mereka serta lingkungan anak yang kurang mendukung sehingga anak salah dalam bergaul, dan jika dilihat dari pemahaman orang tua dalam memaknai pentingnya pendidikan lanjutan bagi anak para orang tua sudah mulai mengerti bagaimana pentingnya pendidikan dimasa yang akan datang. Dari penelitian ini dapat disimpulkan bahwa, ada faktor internal dan faktor eksternal yang membuat anak tidak melanjutkan pendidikan yakni dari dalam diri anak itu sendiri, sedangkan dari internal adalah ekonomi, keluarga, dan pergaulan anak. 


\section{Pendahuluan}

Pendidikan bagi kehidupan umat manusia merupakan kebutuhan mutlak yang harus dipenuhi sepanjang hayat. Tanpa pendidikan sama sekali, mustahil suatu kebutuhan pokok manusia dapat terpenuhi dan hidup berkembang sejalan dengan aspirasi (cita-cita) untuk maju, sejahtera, dan bahagia menurut konsep pandangan hidup mereka (Fuad Ihsan 1997: 2).

Dewasa ini, dunia pendidikan semakin tumbuh dan berkembang menyesuaikan diri dengan zaman. Pendidikan merupakan faktor yang sangat penting dalam kehidupan. Seluruh elemen masyarakat mulai menyadari tentang perannya pendidikan dalam merubah kualitas hidup seseorang di masa yang akan datang (Juwariyah 2010: 46).

Pendidikan lanjutan adalah pendidikan yang menuju tingkat yang lebih tinggi. Untuk saat ini pendidikan ini sangatlah penting, karena dunia kerja yang semakin menuntut kemajuan, maka dituntut pula pendidikan yang semakin baik. Selain itu, pendidikan lanjutan kini menjadi syarat dalam menduduki beberapa jabatan khusus yang membutuhkan skill yang mumpuni. Dunia kerja yang semakin maju menyebabkan banyak sekali perubahan dalam sistem pendidikan.

Motivasi orang tua kepada anak termasuk salah satu tugas yang harus dilakukan oleh orang tua. Hal ini sangat penting bagi seorang anak sehingga ia dapat belajar lebih giat tanpa ada perasaan bosan dan lelah. Orang tua yang memotivasi anak cenderung dapat meningkatkan minat dalam diri anak. Sebab motivasi yang diberikan oleh orang tua kepada anaknya sangat dibutuhkan dalam kegiatan belajar (Ahmad Rohani, 2004: 12).

Penelitian ini dilakukan di Desa Gunung Besar, Kecamatan Arma Jaya, Kabupaten Bengkulu Utara. Berdasarkan pengamatan yang sudah dilakukan sebelumnya, di desa ini terdapat penurunan mengenai pendidikan yang dialami oleh masyarakat setempat. Pendidikan adalah hal yang sangat penting bagi masyarakat, terutama pada anak-anak yang memang sudah seharusnya mengenyam pendidikan sesuai dengan tahapannya, tapi itu tidak terjadi. Banyak anak-anak yang tidak bisa melanjutkan pendidikan selayaknya anak-anak seperti umumnya. Setiap tahunnya, ditemukan semakin banyak anak-anak yang tidak melanjutkan pendidikan. Di sini orang tua juga berperan untuk memberikan apa yang seharusnya anak-anak rasakan salah satunya pendidikan itu sendiri. Motivasi pertama yang anak rasakan adalah motivasi dari orang tua. Seharusnya orang tua yang memberikan motivasi agar anak bisa tetap melanjutkan pendidikan yang lebih tinggi lagi. Maka dari itu peneliti ingin mengetahui bagaimana motivasi orang 
Resy Mahalelita, Suryani, dan A. Suradi: MOTIVASI ORANG TUA DALAM MEMBERIKAN PENDIDIKAN LANJUTAN BAGI ANAK DI DESA GUNUNG BESAR KECAMATAN ARMA JAYA KABUPATEN BENGKULU UTARA

tua dalam melanjutkan pendidikan anak-anak mereka.

Masalah ini pun mengalami peningkatan pada setiap tahunnya, di mana anak-anak yang seharusnya melanjutkan keperguruan tinggi atau pendidikan lanjutan harus menikah di usia yang masih belia. Hal ini salah satunya disebabkan oleh kehamilan di luar nikah, sebagai akibat kelalaian memantau anak-anak mereka. Di samping itu, tidak hanya dari kalangan masyarakat menengah ke bawah saja yang tidak bisa melanjutkan pendidikan lanjutan. Namun, ditemukan pula anak-anak dari masyarakat yang berekonomi atas yang mengalami putus pendidikan. Yang ingin peneliti ungkapkan dalam artikel ini adalah bagaimana motivasi orang tua dalam memberikan pendidikan lanjutan? Serta adakah faktor-faktor yang mempengaruhi motivasi orang tua dalam memberikan pendidikan lanjutan anak di Desa Gunung Besar?

Tujuan dari penelitian ini adalah untuk mengetahui motivasi orang tua dalam memberikan pendidikan lanjutan bagi anak di desa Gunung Besar Kecamatan Arma Jaya Kabupaten Bengkulu Utara dan untuk mengetahui faktor-faktor yang memengaruhi orang tua dalam memberikan pendidikan lanjutan bagi anak di Desa Gunung Besar Kecamatan Arma jaya Kabupaten Bengkulu Utara.

Adapun jenis penelitian yang digunakan adalah penelitian lapangan dengan menggunakan pendekatan deskriptif kualitatif yaitu mengunggapkan dan mendeskripsikan bagaimana motivasi orang tua dalam memberikan pendidikan lanjutan bagi anak Didesa Gunung Besar Kecamatan Arma Jaya Kabupaten Bengkulu Utara.

\section{Pembahasan}

Sebelum melakukan wawancara kepada responden, terlebih dahulu peneliti melakukan observasi untuk mengetahui segala sesuatu yang berkaitan dengan motivasi orang tua dalam memberikan pendidikan lanjutan bagi anak di Desa Gunung Besar Kecamatan Arma Jaya Kabupaten Bengkulu Utara. Pada bagian ini pendidikan lanjutan dikategorikan sebagai pendidikan yang berkesinambungan mulai dari Sekolah Dasar hingga Perguruan Tinggi. Orang tua di sini memiliki salah satu peran penting, yakni sebagai pendorong atau motivator bagi anak.

Menurut Kurt Singer (2007: 22) bahwa indikator yang pertama adalah dorongan dari orang tua yang berarti adanya keikutsertaan orang tua dalam pendidikan anak karena dengan adanya keseimbangan motivasi dari orang tua dan anak, anak akan bisa beraktifitas dengan sebaik mungkin tanpa merasa terbebani.

Dengan adanya dorongan dari orang tua anak akan merasa ada dukungan tersendiri dari keluarga 
mereka. Di Desa Gunung Besar yang mayoritas penduduk dengan jenjang pendidikan yang bervariasi membuat sebagian orang tua seolah tak peduli akan apa yang dinamakan motivasi. Sebagaimana dikemukakan oleh Basri, selaku masyarakat setempat mengungkapkan, "Sebagai orang tua, saya memberikan motivasi kepada anak saya dalam melanjutkan pendidikan minimal batas sekolah menengah atas (SMA), karena kalau hanya sebatas SMP, anak masih belum memiliki keterampilan yang baik."

Dalam memberikan dorongan seperti ini, memang diperlukan pemahaman orang tua, agar anak dapat memahami pendidikan di masa depan. Seperti yang diungkapkan Kepala Desa Desa Gunung Besar, Bapak Zainal Abidin mengatakan bahwa, "Seharusnya orang tua juga paham atau mengerti mengenai pendidikan. Dengan adanya pemahaman ini, orang tua bukan hanya memberikan dorongan atau motivasi. Namun, hendaknya mereka juga memberi tahu pengaruh pendidikan di masa depan anak. Dengan demikian anak akan memiliki bayangan tersendiri jika berhenti di jenjang pendidikan tertentu". Hal senada juga diungkapkan oleh saudara Hesti Marelna yang mengungkapkan bahwa,"Saya tidak melanjutkan sekolah lagi karena memang ada faktor ekonomi yang kurang mendukung. Pendidikan hanya sebatas Sekolah menengah atas (SMA) sudah membuat saya bersyukur. Untuk melanjutkan pendidikan ke Perguruan Tinggi orang tua saya sudah tidak sanggup lagi, padahal saya pernah mendapatan undangan masuk dari salah satu Perguruan Tinggi."Berdasarkan pernyataan di atas, bahwa memang setiap orang tua sudah memberikan arahan yang baik. Namun, karena faktor ekonomi membuat pendidikan anak tak dapat dilanjutkan. Selain itu, lingkungan juga sangat berpengaruh.

\section{a. Adanya Harapan dan Cita-Cita Anak}

Berdasarkan hasil observasi peneliti yang sudah dilaksanakan terdapat peran orang tua dalam memberikan harapan kepada anak. Dalam hal ini apabila seseorang telah mempunyai dorongan dan kebutuhan dalam melakukan sesuatu, maka timbul cita-cita akan sesuatu. hal ini juga diungkapkan oleh Bapak Yanuar bahwa, "Karena dari waktu kecil saja kita sering diberi tahu bahwa jika pendidikan tinggi dapat menunjukkan bahwa ada cita-cita kita yang harus tercapai. Sebagai orang tua kami tau apa yang ingin dicita-citakan. Dengan adanya cita-cita dan tujuan pastinya nanti anak juga bisa bersekolah dengan baik. Namun permasalahnnya adalah terkadang anak yang masih belum menemukan apa yang hendak dicita-citakannya."

Hal ini dipertegas juga oleh salah satu orang tua yang anaknya tidak bisa melanjutkan sekolah, yakni Bapak Tono mengungkapkan bahwa, 
Resy Mahalelita, Suryani, dan A. Suradi: MOTIVASI ORANG TUA DALAM MEMBERIKAN PENDIDIKAN LANJUTAN BAGI ANAK DI DESA GUNUNG BESAR KECAMATAN ARMA JAYA KABUPATEN BENGKULU UTARA

“Iya, kami pernah menyarankan agar anak tetap melanjutkan pendidikan supaya masa depannya lebih baik, jika tidak memiliki pendidikan yang mumpuni paling-paling hidupnya harus berakhir di ladang saja."Mengingat hal di atas, terdapat keterkaitan antara pendidikan dengan cita-cita. Seharusnya hal ini sudah dipikirkan sejak lama. Soal cita-cita memang diserahkan kepada anak. Namun, orang tua juga berhak memberikan saran sesuai dengan potensi anak.

Cita-cita atau harapan adalah salah satu jalan agar anak bisa merintis pendidikan mereka sesuai apa yang diinginkan, tetapi jika pendidikan saja tidak bisa dilanjutkan bukan berarti cita-cita tidak tercapai. Masih ada harapan yang ada di setiap anak (Sardiman, 2014: 73). Dari pendapat di atas dapat disimpulkan bahwa harapan yang ada pada diri seorang anak akan tetap berkembang walaupun pendidikan mati di tengah jalan.

\section{b. Penghargaan Kepada Anak}

Memberikan penghargaan kepada anak baik berupa hadiah atau pujian adalah salah satu upaya agar anak lebih termotivasi lagi untuk mengadakan perubahan. Orang tua sudah seharusnya memberikannya meski sedikit. Selebihnya orang tua harus memiliki cara untuk membujuk anaknya untuk tetap bersekolah. Seperti yang diungkapkan oleh ibu Juwita adalah sebagai berikut, "Orang tua juga dapat memberikan hadiah kepada anaknya yang berprestasi. Disamping itu, orang tua juga seharusnya menjelaskan apa yang bisa mereka capai jika melewati sebuah pendidikan. Ya dalam hal ini semampu orang tua untuk mendukung anak-anak mereka."

Selain itu, bentuk lain dalam penghargaan berupa pemberian fasilitas kendaraan pribadi untuk bersekolah. Seperti yang dijelaskan oleh Bapak Ahmi, yaitu, "Saya waktu itu memberikan anak saya motor, supaya dia mau bersekolah. Karena memang jarak antara sekolah dan rumah lumayan jauh. Tapi ketika lulus sekolah menengah Atas (SMA), saya menginginkan dia melanjutkan perguruan tinggi di Bengkulu Utara. Namun, karena sudah tak berminat lagi untuk kuliah, maka anak saya berhenti di tengah jalan."

Hal senada juga diungkapkan oleh ibu Nawai, yaitu, "Pertama saya membujuk dulu, apa akibat jika minim pendidikan. Namun jika sudah dinasehati, semuanya saya kembalikan lagi kepada anak. Anak tidak bisa dipaksakan. Nanti malah hanya akan menghabiskan banyak biaya sebagai akibat ketidakmampuan menyelesaikan pendidikannya."

Dari pernyataan di atas, dapat dipahami bahwa memang harus adanya keselarasan antara motivasi orang tua dan minat anak. Selain itu, antara pemahaman orang tua dan juga faktor ekonomi juga turut mendukung hal tersebut. 


\section{c. Orang Tua Memberikan} Lingkungan yang Baik untuk Anak

Di Desa Gunung Besar anakanak sudah mengerti akses internet. Di mana akses ini dapat memberikan pengaruh negatif. Oleh karena itu, orang tua dituntut untuk memberikan pengawasan lingkungan. Hal ini diungkapkan oleh Kepala Desa Gunung Besar Bapak Zainal Abidin bahwa, "Iya, untuk beberapa tahun ini bisa dilihat anak-anak yang baru lulus Sekolah menengah atas sudah menikah, sudah punya anak, karena faktor hamil di luar nikah sebagai akibat pergaulan yang terlalu bebas. Iya di desa sendiri mereka tidak melakukannya. Namun, di luar desa kita sendiri tidak tahu. Karena anak zaman sekarang itu memang lebih pintar dari yang kita kira."

Pengawasan memegang tujuan pendidikan anak. Orang tua sudah seharusnya mengontrol dan mengamati perilaku anaknya baik di dalam maupun di luar rumah. Pengawasan tidak hanya bersifat mengontrol gerak gerik, akhlak, tindak perilaku dan ucapan anak saja, akan tetapi pengawasan juga menjadi alat berjaga-jaga bagi orang tua agar anakanaknya tumbuh sesuai dengan harapan. Oleh karena itu, untuk mencapai tujuan pendidikan, orang tua perlu melakukan pengawasan yang mencakup beberapa aspek kehidupan yaitu: a). Pengawasan terhadap pendidikan aqidah anak; b).
Pengawasan orang tua terhadap pendidikan akhlak dan moral anak; c). Pengawasan orang tua terhadap pengamalan agama anak; d). Pengawasan orang tua terhadap aktivitas ibadah anak.

Faktor-Faktor Yang Mempengaruhi Orang Tua Dalam Memberikan Pendidikan Lanjutan Bagi Anak Di Desa Gunung Besar Kecamatan Arma Jaya Kabupaten Bengkulu Utara

a. Minat anak

Pendidikan bagi manusia adalah yang mutlak untuk kemajuan setiap manusia. Orang tua berperan untuk memberikan dukungan, memberikan fasilitas, memberikan tauladan yang baik serta memberikan pendidikan yang layak. Akan tetapi disini juga anak berperan penting dalam hal pendidikan mereka sendiri. Selepas dari tanggung jawab orang tua, anak tentu harus memiliki minat yang kuat dalam belajar, karena pendidikan yang baik itu akan membawa mereka ke masa depan yang lebih baik. Seperti yang diungkapkan oleh Satiful bahri Djamarah mengenai minat adalah: "Minat adalah kecenderungan yang menetap untuk memperhatikan dan mengenang terhadap aktivitas. Seorang yang berminat terhadap aktivitas akan memperhatikan itu secara konsisten dengan rasa senang (Sayiful Bahri Djamarah 2008:34)." 
b. Faktor keluarga

Keluarga adalah hal terbesar bagi anak, di mana orang tua adalah sebagai faktor pendukung utama anak yang pertama. Seperti yang dijelaskan oleh pendapat Agus Sujanto, dkk. (2001:8), bahwa keluarga yang menghadirkan anak ke dunia ini, secara kodratbertugas mendidik anak. Sejak kecil anak hidup, tumbuh dan berkembangdi dalam keluarga. Seluruh isi keluarga itu yang mula-mula mengisi pribadi anak itu.

c. Pergaulan anak

Anak yang sedang dalam masa perkembangan cenderung memikirkan jati diri mereka ketimbang lebih dewasa memikirkan pendidikan mereka. Menurut Zakiah Drajat (2010: 3233) mengatakan bahwa, terdapat beberapa aspek yang sangat penting yang harus diperhatikan oleh orang tua dalam mengawasi pergaulan anak:

1. Mengawasi anak dalam memilih teman bergaul

Seorang anak memerlukan teman bergaul dan bermain, ini merupakan kebutuhan psikologis anak yang tidak dapat dihindari. Dengan bermain bersama temannya, anak dapat mengembangkan rasa kemasyarakatan, berlatih menjadi pemimpin juga sebagai proses menemukan jati diri. Namun orang tua perlu mengawasi anak dalam memilih teman bergaul karena teman ikut mempengaruhi perkembangan seorang anak. Apabila teman pergaulannya baik, maka anak cenderung akan menjadi baik. Demikian pula sebaliknya, jika seorang anak bergaul dengan teman yang buruk maka kemungkinan ia juga akan mengikuti perilaku-perilaku buruk temannya tersebut.

2. Mengawasi anak dalam memilih tontonan dan hiburan. Kemajuan ilmu pengetahuan yang didukung oleh teknologi yang semakin canggih, memberi konsekuensi terhadap manusia hingga dapat membuat apa saja termasuk berbagai macam bentuk hiburan dan tontonan yang menarik. Berkaitan dengan hal ini, orang tua hendaknya selalu mengawasi anaknya agar mereka tidak melihat tontonan yang sadis dan pornografi. Karena tontonan ini akan mempengaruhi pertumbuhan dan perkembangan jasmani dan rohani anak

Berdasarkan uraian di atas, dapat dipahami bahwa kedua aspek di atas merupakan hal yang sangat 
penting untuk diperhatikan oleh orang tua. Pada umumnya seorang anak yang beranjak remaja cenderung ingin bebas melakukan segala sesuatu. Dalam hal ini orang tua hanya perlu mengawasi atau mengontrol segala aktivitas anak-anaknya. Apabila terdapat kesalahan yang dilakukan oleh anak, orang tua sekurangkurangnya memberi nasehat atau menegur sikap anak tersebut sehingga dapat memperbaiki tingkah lakunya. Adanya pengawasan ini sangat dibutuhkan agar anak tidak terbiarkan berbuat hal-hal yang tidak pantas sejak remaja. Dengan adanya pengawasan dari orang tua, maka pertumbuhan pada diri anak akan menjadi lebih baik di masa depan.

\section{Kesimpulan}

Dalam menempuh jenjang pendidikan, beberapa factor cukup memengaruhi. Salah satunya adalah faktor internal. Factor ini sendiri merupakan faktor yang ada dalam diri anak itu sendiri. Salah satunya adalah minat. Dengan minat anak-anak akan bersemangat dalam menjalani pendidikan. Dengan semangat permasalahan yang muncul dapat ditepis.

Faktor lainnya adalah faktor eskternal. Faktor ini merupakan factor yang mempengaruhi anak dari luar. Seperti keterbatasan ekonomi keluarga yang dapat menghambat pemenuhan kebutuhan akan fasilitas penunjang pendidikan. Serta, faktor lingkungan baik itu dari keluarga atau masyarakat yang mempengaruhi pola pikir dan tingkah laku anak dalam memberikan keputusan.

\section{DAFTAR PUSTAKA}

Agus Sujanto, dkk. 200. Psikologi Kepribadian Cet.XI. Jakarta: Bumi Aksara.

Ahmad Rohani. 2004. Pengelolaan Pengajaran. Jakarta : Rineka Cipta.

Fuad Ihsan. Dasar - Dasar Kependidikan,Cet.1. Jakarta :PT. Rikena Cipta.

Juwariyah. 2010. Dasar-Dasar Pendidikan Anak dalam Al-Qur'an. Yogyakarta: Teras.

Kurt Singer. 2007. Membina Hasrat Belajar Di Sekolah. Bandung : Remaja Rosda Karya.

Sardiman. 2014. Interaksi Dan Motivasi Belajar-Mengajar. Jakarta : PT Raja Grafindo Persada.

Syaiful Bahri Djamarah. 2004. Pola Komunikasi Orang Tua dan Anak dalam Keluarga. Jakarta: Rineka Cipta.

Zakiah Daradjat. 2010. IlmuPendidikan Islam. Jakarta: BumiAksara. 